\title{
Analisa Persepsi Customer Feedback E-Commerce Tokopedia Menggunakan Text Network Analysis
}

\author{
Desi Febriani \\ 175100042p \\ Fakultas Komputer \\ desifebriani.student@umitra.ac.id
}

\begin{abstract}
Kemajuan teknologi informasi telah membawa peluang bagi bisnis untuk mengembangkan bisnisnya. Pengguna media. Penelitian ini termasuk jenis penelitian kualitatif deskriptif. Penelitian kualitatif deskriptif adalah penelitian yang bertujuan untuk sosial yang semakin meningkat setiap tahunnya menjadikan media sosial menjadi tools perusahaan untuk melihat konsumennya. Perusahaan harus mengetahui analisis media sosial dengan cara yang tepat sesuai dengan rencana bisnis perusahaan. Pemakaian media sosial oleh pengguna telah menghasilkan data jejak keseharian individu dimana terdapat pandangan seseorang terhadap suatu obyek. Data yang terkumpul dengan ukuran yang besar dalam media sosial dan bersifat kompleks tersebut adalah big data. Pemanfaatan social computing dapat digunakan untuk menganalisis pola yang terdapat pada big data. Salah satu tool dari social computing yaitu Text Network Analysis (TNA) adalah teknik penelitian yang berfokus pada identifikasi dan membandingkan hubungan jaringan antara kata, kalimat dan sistem untuk memodelkan interaksi yang menghasilkan pengetahuan atau informasi yang baru. Dalam penelitian ini Text Network Analysis (TNA) akan menunjukkan asosiasi persepsi konsumen melalui customer feedback yang diberikannya pada media social terrhadap $e$-commerce Consumer to Consumer (C2C) terbesar di Indonesia yaitu Tokopedia dan Bukalapakmendeskripsikan karakteristik dari suatu objek, orang, grup, organisasi atau lingkungan yang menggambarkan situasi atau kejadian tertentu. Data pada penelitian ini yaitu data sekunder dengan cara crawling data pada media sosial Twitter dengan menggunakan metode analisis yaitu Text Network Analysis (TNA). Hasil asosiasi persepsi dari pengolahan data di media sosial melalui Text Network Analysis (TNA) dapat digunakan bisnis e-commerce sebagai marketing intelligence.
\end{abstract}

Kata Kunci : Text Network Analysis, Customer Feedback, Persepsi, Big Data 


\section{A. PENDAHULUAN}

Kemajuan Teknologi yang menjadi salah satu kebutuhan penting masyarakat menyebabkan teknologi mengendari dunia. Salah satu fenomena teknologi yang sedang berkembang adalah social media. Pengguna media sosial yang semakin meningkat setiap tahunnya menjadikan media sosial menjadi tools perusahaan untuk melihat konsumennya. Dikarenakan masyarakat Indonesia yang adaptif terhadap teknologi menyebabkan terjadi peningkatan pengguna media sosial di Indonesia. Pada tahun 2017, terjadi peningkatan dari 79 juta pengguna pada Januari 2016 menjadi 106 juta pengguna pada Januari 2017.

Sehingga perusahaan harus mengetahui analisis media sosial dengan cara yang tepat sesuai dengan rencana bisnis mereka.

Perkembangan media sosial di Indonesia disebabkan karena adanya perkembangan internet di Indonesia. Berdasarkan riset dari We Are Social tanggal 26 Januari 2017 bahwa terjadi peningkatan pengguna internet di Indonesia selama setahun, mulai Januari 2016 sampai Januari 2017, yakni sebanyak 132,7 juta pengguna dari 88,1 juta pengguna.

Perkembangan internet menyebabkan pula perubahan bisnis menjadi bisnis yang berbasis digital sehingga munculnya $e$-commerce. Dari survei yang dilakukan badan survei telematika, We Are Social bahwa terjadi peningkatan sebesar $12 \%$ menjadi 24,74 juta pengguna internet yang berbelanja secara online melalui e-commerce.

Konsumen Indonesia mulai mengadopsi budaya belanja online disebabkan pula dikarenakan munculnya berbagai bisnis e-commerce di Indonesia. Berbagai jenis $e$ commerce terdapat di Indonesia, salah satunya adalah bisnis e-commerce $\mathrm{C} 2 \mathrm{C}$ (Consumer to Consumer). Bisnis ecommerce $\mathrm{C} 2 \mathrm{C}$ merupakan bisnis online dengan user (pengguna) yang dapat berjualan di marketplace tersebut sehingga user dapat menjadi penjual ataupun pembeli. Berdasarkan survei konvensional yang dilakukan oleh topbizz pada tahun 2016 dalam Sharing Vision bahwa e-commerce C2C yang memiliki tingkat awareness tertinggi adalah Tokopedia dengan nilai 45,2 dan Bukalapak dengan nilai 36,9. Pemanfaatan social computing dapat digunakan untuk menganalisis pola yang terdapat pada big data. Social computing merupakan ilmu yang berfokus tentang perilaku sosial dan konteks sosial menggunakan sistem komputasi.

\section{B. PEMBAHASAN / STUDI KASUS}

Penelitian yang dilakukan merupakan penelitian deskriptif. Penelitian deskriptif dilakukan untuk menjelaskan karakteristik dari variabel yang sedang diteliti. Tujuan dari penelitian deskriptif dalam 
$\begin{array}{lrr}\text { bisnis } & \text { adalah } & \text { untuk } \\ \text { menggambarkan } & \text { karakteristik } \\ \text { dari } & \text { suatu } & \text { group, }\end{array}$ memperkirakan persentase dari suatu unit yang di analisis dan mengetahui persepsi dari pengguna produk. Selain itu penelitian ini termasuk penelitian kualitatif. Penelitian dalam pendekatan kualitatif sering digunakan untuk melihat lebih dalam suatu fenomena sosial termasuk di dalamnya kajian terhadap ilmu pendidikan, manajemen dan administrasi bisnis, kebijakan publik, pembangunan ataupun ilmu hukum.

Metode penelitian yang digunakan adalah Text Network Analysis (TNA). Text Network Analysis adalah analisis text yang merupakan bagian dari social computing yang memungkinkan analisis terkait hubungan antar kata sehingga membentuk pola yang memiliki arti. Adapun tahapan penelitian dapat dilihat pada gambar 1 .

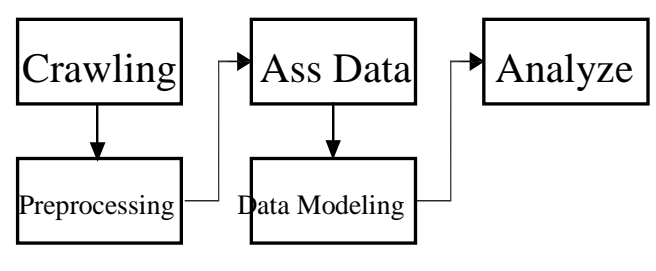

Crawling data dilakukan di media sosial Twitter selama 1 minggu yaitu pada tanggal 16 Oktober 2017 - 23 Oktober 2017 dengan menggunakan aplikasi pemrogaman $\mathrm{R}$ Studio.

Hasil tweets yang berhasil di crawling, yaitu:

\begin{tabular}{|r|l|}
\hline Nama $\boldsymbol{e}$ & \multicolumn{1}{c|}{ Hasil Crawling Tweets } \\
\hline Tokopedia & 6.768 tweets \\
\hline Bukalapak & 21.265 tweets \\
\hline
\end{tabular}

Dapat dilihat pada Tabel I, bahwa tweets yang telah dicrawling terhadap interaksi user di sosial media Twitter mengenai e-commerce Tokopedia sebanyak 6768 tweets, sedangkan tweets terhadap interaksi user di sosial media Twitter mengenai e-commerce bukalapak sebanyak 21265 selama periode pengambilan data yaitu 16 Oktober 2017 sampai dengan 23 Oktober 2017.

\section{B. Persepsi Dominan Mengenai Tokopedia di Twitter}

Setelah melewati preprocessing data maka katakata yang diutarakan konsumen mengenai persepsi mereka terkait Tokopedia dilakukan analisis dengan word cloud sehingga menghasilkan 40 kata dominan yang mewakili persepsi dominan konsumen mengenai Tokopedia di Twitter.

\section{ID SECURITY \\ QWTD4452377-ASP-5244107}

\section{KESIMPULAN}

Dapat Pada paper ini menunjukkan melalui Text Network Analysis, peneliti dapat memodelkan persepsi konsumen dengan baik. Melalui crawling data di media sosial, peneliti dapat 
melihat customer feedback yang diberikan terkait bisnis $e$ commerce. Pada analisis menggunakan word cloud dapat dilihat kata dominan yang mempengaruhi persepsi konsumen terhadap bisnis $e$ commerce sedangkan dengan Text Network Analysis (TNA) dapat dilihat asosiasi dari persepsi tersebut yang menciptakan kluster berdasarkan hubungan antar kata sehingga dapat dilihat asosiasi persepsi positif dan asosiasi persepsi negatif dari hasil crawling data di media sosial Twitter mengenai bisnis e-commerce.

Dapat disimpulkan bahwa asosiasi persepsi yang dibentuk oleh e-commerce Tokopedia menciptakan asosiasi persepsi positif yang dominan sehingga hal ini menandakan bahwa

pelayanan dan sistem $e$ commerce Tokopedia sudah baik hal

ini terlihat pula dengan katakata dominan yang muncul yaitu "murah", "cepat", "senang" dan "beli" yang menandakan bahwa konsumen senang berbelanja di Tokopedia karena cepat dan murah. Selain itu Tokopedia juga memiliki asosiasi persepsi negatif yang perlu diperbaiki mengenai "akun", "login" dan lain-lain. Pada percakapan di media sosial mengenai Bukalapak terbentuk asosiasi persepsi negatif yang lebih dominan sehingga Bukalapak harus bertindak mengantisipasi persepsi negatif di media sosial, hal yang dapat dianalisis melalui asosiasi persepsi negatif tersebut adalah Bukalapak harus memperbaiki sistem ataupun website yang error dikarenakan membuat kesal konsumen hal ini terbentuk dari asosiasi antara kata "website", "error", dan "kesal". Bukalapak juga dapat memanfaatkan asosiasi persepsi positif untuk membantu menyenangkan konsumen dan sebagai brand image perusahaan.

\section{E. DISKUSI}

\begin{tabular}{lr}
\multicolumn{2}{c}{ Saya bersama teman saya } \\
bernama Sarah & Aulia \\
mendiskusikan & tentang \\
Kelebihan & analisis \\
menggunakan Text & Network \\
Analysis &
\end{tabular} (TNA) dibanding metode lainnya untuk melihat persepsi konsumen seperti Multi Dimensional Scaling (MDS) adalah

biaya yang lebih dibutuhkan rendah, lebih real time dan lebih mencakup area yang lebih luas karena crawling dari media sosial. Sehingga perusahaan bisnis dapat memanfaatkannya untuk meningkatkan Customer Relationship Management (CRM) dengan melihat persepsi konsumen yang terbentuk karena memungkinkan bisnis mengikuti opini publik terkait image e-commerce dan merespon terhadap masalah pelanggan terkait persepsi 


\section{F. REFERENCE}

[1] O. M. Febriani and A. S. Putra, "Sistem Informasi Monitoring Inventori Barang Pada Balai Riset Standardisasi Industri Bandar Lampung," J. Inform., vol. 13, no. 1, pp. 90-98, 2014.

[2] A. S. Putra, "Paperplain: Execution Fundamental Create Application With Borland Delphi 7.0 University Of Mitra Indonesia," 2018.

[3] A. S. Putra, "2018 Artikel Struktur Data, Audit Dan Jaringan Komputer," 2018.

A. S. Putra, "ALIAS MANAGER USED IN DATABASE DESKTOP STUDI CASE DB DEMOS." A. S. Putra, "COMPREHENSIVE SET OF PROFESSIONAL FOR DISTRIBUTE COMPUTING."

[6] A. S. Putra, "DATA ORIENTED RECOGNITION IN BORLAND DELPHI 7.0."

[7] A. S. Putra, "EMBARCADERO DELPHI XE 2 IN GPUPOWERED FIREMONKEY APPLICATION."

[8] A. S. Putra, "HAK ATAS 
KEKAYAAN INTELEKTUAL

DALAM

DUNIA

TEKNOLOGY BERBASIS

REVOLUSI INDUSTRI 4.0.'

[9] A. S. Putra, "IMPLEMENTASI

PERATURAN

PERUNDANGAN UU. NO 31

TAHUN 2000 TENTANG

DESAIN INDUSTRI

BERBASIS INFORMATION TECHNOLOGY."

[10]

$\begin{array}{lr}\text { A. S. } & \text { Putra, } \\ \text { "IMPLEMENTATION } & \text { OF }\end{array}$ PARADOX DBASE."

[11] A. S. Putra, "IMPLEMENTATION OF TRADE SECRET CASE STUDY SAMSUNG MOBILE PHONE."

[12] A. S. Putra, "IMPLEMENTATION

PATENT FOR APPLICATION

WEB BASED CASE STUDI

WWW. PUBLIKLAMPUNG. COM."

[13] A.

"IMPLEMENTATION

SYSTEM FIRST TO INVENT IN DIGITALLY INDUSTRY."

[14] A. S. Putra, "MANUAL REPORT \& INTEGRATED DEVELOPMENT

ENVIRONMENT BORLAND DELPHI 7.0."

[15] A. S. Putra, "PATENT AS RELEVAN SUPPORT RESEARCH."

[16] A. S. Putra, "PATENT FOR RESEARCH STUDY CASE OF APPLE. Inc."

[17] A. S. Putra, "PATENT PROTECTION FOR APPLICATION INVENT."

[18] A. S. Putra, "QUICK REPORT IN

PROPERTY
PROGRAMMING."

[19] A. S. Putra, "REVIEW CIRCUIT LAYOUT COMPONENT

REQUIREMENT ON ASUS NOTEBOOK."

[20] A. S. Putra, "REVIEW TRADEMARK PATENT FOR INDUSTRIAL TECHNOLOGY BASED 4.0."

[21] A. S. Putra, "TOOLBAR COMPONENT PALLETTE IN OBJECT ORIENTED PROGRAMMING."

[22] A. S. Putra, "WORKING DIRECTORY SET FOR PARADOX 7."

[23] A. S. Putra, "ZQUERY CONNECTION

IMPLEMENTED

PROGRAMMING STUDI CASE PT. BANK BCA Tbk."

[24] A. S. Putra, D. R. Aryanti, and I. Hartati, "Metode SAW (Simple Additive Weighting) sebagai Sistem Pendukung Keputusan Guru Berprestasi (Studi Kasus: SMK Global Surya)," in Prosiding Seminar Nasional Darmajaya, 2018, vol. 1, no. 1, pp. 85-97.

[25] A. S. Putra and O. M. Febriani, "Knowledge Management Online Application in PDAM Lampung Province," in Prosiding International conference on Information Technology and Business (ICITB), 2018, pp. 181-187.

[26] A. S. Putra, O. M. Febriani, and B. Bachry, "Implementasi Genetic Fuzzy System Untuk Mengidentifikasi Hasil Curian Kendaraan Bermotor Di Polda Lampung," SIMADA (Jurnal 
Sist. Inf. dan Manaj. Basis

Data), vol. 1, no. 1, pp. 21-30, 2018.

[27] A. S. Putra, H. Sukri, and K. Zuhri, "Sistem Monitoring Realtime Jaringan Irigasi Desa (JIDES) Dengan Konsep Jaringan Sensor Nirkabel," IJEIS (Indonesian J. Electron. Instrum. Syst., vol. 8, no. 2, pp. 221-232.

[28] D. P. Sari, O. M. Febriani, and A. S. Putra, "Perancangan Sistem Informasi SDM Berprestasi pada SD Global Surya," in Prosiding Seminar Nasional Darmajaya, 2018, vol. 1, no. 1, pp. 289-294. 